Article

\title{
Indian Scientists' Definitions of Religion and Spirituality
}

\author{
Simranjit Khalsa ${ }^{1}$, Brenton D. Kalinowski ${ }^{2, *}$ and Elaine Howard Ecklund ${ }^{2}$ \\ 1 Department of Sociology, The University of Memphis, Memphis, TN 38152, USA; skhalsa@memphis.edu \\ 2 Department of Sociology, Rice University, 6100 Main Street, MS-28 Houston, TX 77005 USA; ehe@rice.edu \\ * Correspondence: bkalinowski@rice.edu
}

Received: 8 June 2020; Accepted: 7 July 2020; Published: 13 July 2020

\begin{abstract}
Scientists are often assumed to be irreligious and little research has examined the role of religion and spirituality in their lives. Recent research shows that many scientists do articulate a commitment to the sacred and see religion and spirituality as influencing their work. However, we lack a basic understanding of how scientists define religion and spirituality, particularly outside of the Western world. We examine Indian Scientists' definitions of religion and spirituality and their tie to scientists' views on the relationship between religion and science. Drawing on 80 in-depth interviews with Indian scientists, we find that although science often operates as a global institution, national context influences definitions of religion and spirituality. Further, the views a scientist has about the relationship between religion and science are linked to their definition of religion. To understand and navigate the relationship between religion and science, we must study definitions of religion and spirituality, as well as the way they are shaped by national context.
\end{abstract}

Keywords: religion and science; India; sociology of religion; spirituality

\section{Introduction}

Scholars of religion have long struggled with defining religion, and these difficulties have only been exacerbated by the rise of those who consider themselves spiritual but not religious and the growing number of people who claim no religious affiliation or the "religious nones" (Smith et al. 2013). Given the increasing diversity in approaches to the sacred, it has become even more important to understand how people define religion and spirituality. Definitions of religion and spirituality can shed light on the role both religion and spirituality continue to play in people's day-to-day lives (Schlehofer et al. 2008).

Although there is a growing body of literature related to how individuals define these terms, one population that has not received much attention is the scientific community. People have often looked to science as a conduit of secularism and an opponent of religion and religious thinking (Baker 2012), and the degree of scientists' lack of religiosity is consistently overstated (Ecklund 2010). Studying scientists' definitions of religion and spirituality, and their connection to views on the relationship between religion and science, may help us understand the conditions under which tensions between religion and science emerge as well as the conditions under which religion and science work together.

Further, research on definitions of religion and spirituality has been largely limited to the Western world (i.e., Ecklund and Long 2011), despite evidence for the contextual nature of both religion and views on the relationship between religion and science (Jaeshik 2016; Keller et al. 2013; Southgate 2016). Studying definitions of religion and spirituality across national contexts can shed light on the ways in which different religious contexts, and different definitions of religion and spirituality, are linked to various understandings of the relationship between religion and science. The Indian context is markedly different from other national contexts, particularly in the Western world. India 
is characterized by great religious, cultural, and linguistic variety (Bhattacharyya 2001), that is quite distinct from those dominant in the Western world, and it is reasonable to expect these differences may be tied to both definitions of religion and spirituality and views on the relationship between religion and science.

Although context matters, as we will show, it is also important to consider that science often operates as a global field, functioning across national boundaries with scientists in different national contexts, particularly in the West, maintaining strong international ties (Schott 1993; Schott 1998). Recent decades have marked rapid growth in India's science and technology infrastructure and consumption of these technologies (Kumar 2012); however, growth has been strongly influenced by the science infrastructure of the West, primarily through the British colonization of India (Bhattacharya 2011). Scientific institutions mirror each other and institutions from across the globe are tied together in joint research endeavors. Even the education of scientists (especially scientists who work at top research universities) becomes transnational, with many scientists from countries such as India and China traveling abroad to obtain their degrees (Sidhu 2006). It has been unclear how the ties scientists have across national contexts have shaped their understandings of religion and spirituality and the implications these ties have for the relationship between religion and science. By studying Indian scientists' definitions of religion and spirituality, we aim to better understand the extent to which science is a global discipline in which scientists largely share similar beliefs and attitudes about religion and spirituality, the extent to which national context is linked to these beliefs and attitudes, and what the implications of particular understandings of religion and spirituality are for the relationship between religion and science. As we will show, in comparison to what other works have found to be common among Western scientists, Indian scientists often define spirituality in similarly individualized terms and are less readily able to define spirituality than they are to define religion. Indian scientists defer, however, by placing a greater emphasis on ritual and the ways it can aid or detract from scientific work which may shape the way they look at their religious or spiritual identity and their work.

\section{Definitions of Religion and Spirituality}

The role of religion in society has shifted in recent years, with the presence and influence of religion in society changing, and scholars continue to debate the form religion takes in the modern world (Chaves 1994; Bellah 1985; Norris and Inglehart 2004; Wuthnow 1988). One of the many changes to the global religious landscape is the rise of spirituality, and with this change scholars have investigated the relationship between religion and spirituality (Hill et al. 2000; Zinnbauer et al. 1997). Nancy Ammerman (2013) points to spirituality as an emergent and contested term in common usage with individuals who apply the label to themselves having a variety of conceptions of what it means. Ammerman (2013) also notes that the classical scholarly discourse of spirituality has often defined it as having the common characteristics of some degree of dissociation from organized religion, a willingness to draw from multiple sources of sacred knowledge, and an adherence to individuality. Spirituality is also often defined by the way in which it is distinct from religion. A common distinction between religion and spirituality in the West presents religion as being about specific practices, rituals, and beliefs while spirituality is more personal and independent. Similarly, researchers find that people think of religion as a source of community, whereas spirituality is a much more individual phenomenon (Schlehofer et al. 2008). Wuthnow (1998) presents a model of spirituality in America, which he describes as "practice-oriented spirituality," highlighting the need for personal discipline and doing good works for the benefit of humanity. Despite these differences between religion and spirituality, there are similarities between them as well. For example, Hill et al. (2000) show the emergence of spirituality within religious contexts. Scholars do find that there are more similarities between people's concept of religion and spirituality than there are differences and that these two concepts are not necessarily opposed (Marler and Hadaway 2002; Schlehofer et al. 2008). For our purposes, we do not put forward one specific definition of spirituality, but rather seek to understand how our respondents conceptualize the term for themselves. 


\section{Scientists' Definitions of Religion and Spirituality}

Although we have a general understanding of how people in Western contexts define religion and spirituality, little research has been done on scientists' definitions of these concepts. Much of the existing research on scientists and religion engages with questions of secularization and the relationship between religion and science, assuming that scientists are not interested in religion or are, in fact, opposed to religion (i.e., Larson and Witham 1997, 1998). Science and religion are often perceived to be in conflict, with science representing rationality and religion representing belief and faith. Science itself is often depicted as a conduit of secularism, and secularists demonstrate a high level of faith in science (Larson and Witham 1997, 1998; Leuba 1916). To support this claim, researchers have pointed to the low percentage of scientists and those with a science education who express belief in God (Larson and Witham 1998; Martin and D'Elia 2016). However, this body of work does not assume that religion and science are in conflict (e.g., Martin and D'Elia 2016), but rather that religion is largely absent from science or that it plays a marginal role at best. Although recent sociological research has been critical of the conflict perspective (Baker 2012; Ecklund 2010; Norris and Inglehart 2004), it remains common among the general public and vocal new atheists critical of religion (i.e., Dawkins 2006). Even among populations that tend to advance a narrative of collaboration or independence, young adults for example, they perceive the conflict narrative as dominant in broader society (Coosona 2016). Further, scientists' definitions of religion and spirituality are rarely studied, leaving us with little data to address assumptions that they are irreligious and in conflict with religious belief. Ecklund and Long (2011) seek to challenge this narrative, studying scientists' spirituality and finding that among American scientists, a significant minority of them describe a personal spirituality that is consistent with their identity as scientists, highlighting the search for the truth in an effort to create a spiritual identity that aligns more with science than with religion. They argue that religion and spirituality do emerge among scientists and that scientists who have the most negative view of religion often have the least nuanced narratives of religion (Ecklund and Long 2011). This suggests that it is important to understand scientists' perceptions of religion and spirituality to come to a deeper understanding of the relationship among religion, science, and secularity. Further, Ecklund and Long (2011) suggest that scientists' approach to religion and spirituality is distinct from the general public as scientists strive to create religious and spiritual identities that are consistent with their professional identities. Therefore, there are some scientists who would consider themselves religious rather than spiritual, if it were not for the greater ease to which identifying as spiritual could mediate between their identity as scientists and their sacred beliefs. Based on the nature of the scientific endeavor, scientists can be expected to have a unique need to mediate professional identity with sacred identity. It remains unclear, however, how similar scientists are across national contexts with regard to their understanding of religion and spirituality. Further, research on the relationship between science and religion may presuppose particular understandings of religion. Investigating scientists' definitions of religion and spirituality can shed light on the influence of national context on these definitions and how these definitions are tied to scientists' views on the relationship between religion and science. This is a critical step in understanding and addressing the commonly perceived conflict between science and religion and how this operates across national contexts.

\section{The Contexts of Religion and Spirituality}

There is much evidence that context matters in shaping how people understand religion and spirituality (Garelli 2007; Hautman et al. 2009; Keller et al. 2013), as well as views on the relationship between religion and science (Jaeshik 2016). However, of the minimal research that focuses specifically on scientists' definitions of religion and spirituality, even less has been conducted outside the US or Western Europe. To our knowledge, there has been no rigorous social scientific study of Indian scientists' understandings of religion and science, nor has there been study of their understandings of religion and spirituality in connection to their views on the relationship between religion and science. Religion in the Indian context is markedly different than religion in Western contexts (Gosling 2007), 
and for that reason, we cannot assume that Indian scientists would have a similar understanding of religion and spirituality as scientists in Western contexts. Among the most notable of these differences is the religious plurality in India and the common, although far from universal, result of an acceptance of multiple forms of truth less common in the West. Additionally, religion and culture are particularly difficult to disentangle in the Indian context, and religion is a particularly powerful force structing social dynamics in India (Gosling 2007). Studying this subject in the Indian context is important because the religious characteristics of India are considerably different than in countries such as the US. In India religion is extremely salient among the general population, with $99 \%$ of the population claiming to be religious (Census of India 2011), whereas in the US, one of the most religious Western nations, only $76.5 \%$ of the general public are affiliated with a religion (PEW 2015). Science and scientists in India, however, have been greatly influenced by the West, particularly Britain (Bhattacharya 2011). Further, US and UK scientific institutions often draw on Indian scientists to support their workforce. Indian scientists are, thus, members of a global discipline that may shape their views on religion and spirituality, and reside in a unique national context infused with religion.

Religion played a formative role in the development of Indian society (Coulborn 1958), and India is understood to have a particularly unique religious context, where culture and religion are completely intertwined (Madan 1989). India is characterized by a high level of religiosity (Census of India 2011), and the dominant religion of India is Hinduism, a religion that has markedly different beliefs and practices compared to Christianity, the dominant faith in most Western contexts (Rinehart 2004). India is also marked by a strong tradition of religious support for scientific initiatives (Brooke and Numbers 2011), although the extent to which Hinduism, the dominant religion in India, and science are in conflict is still debated as some have pointed to the contributions of Hindu thinkers and scientists over the past two centuries and earlier (i.e., Brown 2012). In fact, research on religion and science has focused primarily on Christianity (Burdett 2017). This suggests that understandings of religion and spirituality, as well as views on the relationship between religion and science, may be distinct in India compared to Western countries such as the US.

While scholars have suggested that the global scientific community is strongly influenced by Western science (Schofer 2003), the extent to which this influence bleeds into understandings of religion and spirituality is unclear. Indian scientists often immigrate to Western countries, traveling to places such as the US and the UK to complete their PhDs, work in a lab, or work at universities (North 1995; Stephan and Levin 2001). However, there have also been attempts to "decolonize" Indian science; to uncover science in India prior to colonization and to understand its impact on Indian science today (Raina 2012; Sen 2005). One possibility noted by some scholars is that rationality has sometimes been associated with both science and the secular in the West, which pushes religion to the realm of the irrational (Stark et al. 1996). It may be the case that this association of science with rationality and with secularity has had some influence in India. However, the concept "secular" is itself markedly different in India compared to meanings of "secular" in the West (Das Acevedo 2013; Madan 1987; Tejani 2007). The concept of secularism does not travel across borders unchanged, particularly in societies that have not conformed to the pattern of development that marks Western societies beginning with the disenchantment of the world, where the world becomes something that can be fully understood through reason (Taylor 2016; Weber 1918). Although there are some in India who champion the cause of disenchantment (Quack 2012), it has not taken hold among the general population (Taylor 2016). Secularism has been a hotly contested term in India, plagued by the struggle of creating a democratic state (Tejani 2007), and has been tied to a range of meanings from being anti-religion, to being neutral towards all religions, to supporting the religion of the majority population (Bhargava 2010, p. 332). Generally, it is understood to refer to the protection of all religions, and religious minorities, rather than the separation of religion and the state (Rajan and Needham 2007). Further, debates surrounding secularism have become entangled with the issue of religious minorities and how the state should interact with them (Chandhoke 1999; Prakash 2007). In many cases, Western notions of division between religion and politics were largely rejected by Indian political elites (Sen et al. 2013). In fact, 
scholars have argued that notions of spirituality as efforts towards equality and the advancement of humanity must be incorporated into the concept of secularity (Giri 2005). Similarly, key Indian religious and spiritual leaders, such as Swami Vivekananda, have often supported science and pushed for scientific development (Brooke and Numbers 2011). Further, in the Western world, India has often been represented as a site immersed in religion and spiritualty, inspiring a wash of interest, conversion to religions from India, and spiritual tourism in India (Chandra 2015; Goldberg 2010).

By studying how Indian scientists define religion and spirituality, and how such definitions are linked to their views of the relationship between religion and science, we ask how such definitions are shaped by their unique national context and the global nature of the scientific field, whether the conflict paradigm is an invention of the West, as well as whether there are a broader range of possibilities for connecting science and religion. Based on this literature, we ask how Indian scientists view religion and spirituality and how this is connected to their view of the relationship between religion and science.

\section{Methods}

We draw on data from an international research project studying scientists' understanding of religion and spirituality and the connections to their work as scientists (see Ecklund et al. 2019 for detailed methodology). This study was conducted in eight different national contexts: India, the United States, the United Kingdom, France, Turkey, Hong Kong, Taiwan, and Italy. We focus here on the Indian context to better understand the impact of this unique national context on understandings of religion and spirituality among scientists, workers who occupy a global discipline. Our study is a mixed-methods project, using both quantitative and qualitative methods. Our research team constructed a sample frame of all physicists and biologists at higher education institutions in India using Web of Science. We then conducted a survey of 1763 Indian physicists and biologists from this sampling frame with a response rate of $44 \%$. After the survey was complete, we conducted follow-up in-depth interviews with survey respondents who indicated they would be willing to do so. They were selected based on several characteristics including religious affiliation, religiosity, discipline, etc. There were several reasons for our focus on physicists and biologists specifically. First, because these are classic natural science disciplines and many philosophers and sociologists of science posit a hierarchy of disciplines with these two disciplines near the top and with this prestige being reflected in popular perceptions of scientific authority. Additionally, there was more consistency from one department to the next in physics and biology, compared to some other scientific disciplines, which was more appropriate for our comparative approach. Perhaps most importantly, physics and biology come into contact with topics of the natural world in ways that may overlap with big-picture questions in religion such as the origin of the universe and human evolution (Ecklund et al. 2019).

In this paper, we draw on both qualitative and quantitative data to conduct our analysis. In our survey, respondents were asked to "Please indicate which statement best represents you" and choose one of six responses: "conflict, I consider myself to be on the side of science," "conflict, I consider myself to be on the side of religion," "conflict, I am unsure which side I am on," "collaboration, each can be used to help support the other," "independence, they refer to different aspects of reality," and "don't know." We analyzed our interview respondents' definitions of religion and spirituality by separating respondents according to their response to this question on the survey and investigating whether their views on the relationship between religion and science were associated with patterns in respondents' definitions of religion and science.

Our qualitative data draws from a total of 80 in-depth interviews conducted in India; 61 men and 19 women in our sample. These interviews were conducted in person during two research trips to India, over the phone, and over Skype. The interviews range from $27 \mathrm{~min}$ to over $2 \mathrm{~h}$, with most interviews just over an hour long. Our analysis of these data focused on scientists' definitions of religion and spirituality. Although there was some minor variation in wording, the exact questions we asked were: 
Could you give me your working definition of what those terms (religion and spirituality) mean? What is your working definition of "religion," for example?

How about spirituality? Do you have a working definition of the term "spirituality"?

Do you see spirituality as something distinct from religion?

These questions gave us a sense of how our respondents understood these terms as they spoke about the topic of religion and spirituality. Further, we were interested in patterns that stood out as unique to the Indian context.

In the first stage of data analysis, we coded our data using a closed coding scheme. This coding scheme addressed definitions of religion and spirituality, distinguishing between responses that identified characteristics of religion from those that identified the role and effects of religion and then examining common themes within those responses. There were 16 codes on definitions of religion, 9 codes on definitions of spirituality, and 5 codes on the relationship between religion and spirituality. Our team entered a 1 if a code emerged in respondents' narratives and a 0 if it did not. Whenever a 1 was entered, a representative quote was recorded as well. In the next stage of analysis, we analyzed themes that emerged from our closed coding scheme. Finally, after analyzing the qualitative data in isolation, we separated interview respondents according to their responses to the survey question on the relationship between religion and science. We conducted an inductive analysis of these data, looking for trends in respondents' definitions of religion and spirituality within and across their views on the relationship between religion and spirituality. In particular, we were interested in differences in the ways respondents understood religion and spirituality when they viewed the relationship between religion and science as one of conflict, collaboration, and independence.

\section{Results}

We begin by reviewing our respondent's definitions of religion, followed by their definitions of spirituality. Following this, our respondents' views of the relationship between religion and spirituality. Finally, we describe the ways respondent's definitions of religion and spirituality, and the relationship between them, were linked to their view on the relationship between religion and science.

\section{Definitions of Religion}

In our analysis of Indian scientists' narratives using our closed coding scheme, we found that Indian scientists' definitions of religion were marked by great variation, with several respondents discussing each code. The most common code was viewing religion as a source of societal rules and values, brought up by 19 respondents. Among these respondents, however, there was disagreement as to whether this feature of religion was positive or negative. Other respondents view religion primarily as a source of tradition while still others describe it as a set of rituals or practices. Another common understanding of religion, brought up by 16 respondents, was a system of beliefs. These respondents highlight religious dogma and rituals, sometimes leveling this as a critique of religion. Linked to this is the view of religion as a system of rituals and practices, which came up among 10 of our respondents. It was also common for our respondents to link religion to God or a higher power, with 15 respondents doing so. Finally, many of our respondents saw religion as a source of tradition and viewed their own religious identity as ascribed, given to them by birth and carried on for their family's sake.

\subsection{A Higher Power}

For several of our respondents, belief in God or some form of higher power was central to their understanding of religion. One biology graduate student ${ }^{1}$ demonstrates this clearly, saying: "I have not seen a religion that does not believe in God, so God comes with the religion." This makes it very

1 IND_23: Biology, Graduate Student, non-religious, no religious affiliation, male (Because our data comes from a multi-country study, the respondent code IND denotes all our Indian respondents). 
clear how central God is to this respondent's concept of religion. In describing their definitions of religion and discussing God, some respondents described a very personal relationship with God. As one principle scientist in biology ${ }^{2}$ states when asked whether he is involved in a religious tradition: "it's very personal too, so like something you believe in and then kind of think about it, but let's not talk about it openly and not discuss about it." Thus, this respondent describes being very closely tied to God. However, this personal relationship with God is not present for all respondents. Further, it was far more common for our respondents to associate religion with a belief in a higher power or supernatural force than with "God" specifically. For example, another biology graduate student ${ }^{3}$ described religion by saying it was more about "an abstract identity or the perception of God that exists for me." These respondents explicitly reject a concrete and personified notion of God, common in Western contexts, and instead describe a much more abstract force. There is no clearly identifiable trend with regards to viewing religion as a higher power and views on the relationship between religion and science.

\subsection{Religion as a Source of Ethics}

In discussing religion, many of our respondents emphasized functional elements of religion, particularly the role religion plays as a source of ethics and morality. For example, an associate professor of biology ${ }^{4}$ stated that religion is meant to improve humanity-to do good for all human beings, a view which is repeated consistently by other scientists. This perspective is typified by an emeritus biology professor ${ }^{5}$ who described religious people as: "people you know behave in a certain civilized manner in their day-to-day lives with interaction with other people, for example, and you know, being honest with their profession and things like that." Similarly, another biology professor ${ }^{6}$ says: "Just to I mean get the pleasure or you can say to get the blessing of God, you do all good things and that I think is the true religion, because you will avoid doing anything which will displease God." This not only demonstrates the respondents' view that religion is a source of ethics and morality; it also suggests that for this respondent, morality is maintained through the fear of incurring God's displeasure. This is a punitive model of religion in which fear of God enforces positive behavior. Likewise, another professor ${ }^{7}$ argues that religions make people "less notorious" and "up to more discipline," such that "if you believe in something, maybe we do less of crime activity, or nefarious activity maybe."

Many of our respondents believe that religion causes people to avoid unethical conduct and encourages them to be righteous. For some scientists, this development occurred by following a set of predetermined rules, but an assistant biology professor ${ }^{8}$ emphasized the subconscious element of religion:

Religion perhaps is, I mean for me, if I put it in my own words, it's probably something that helps mold a person from a very young age in-in ways that are not fully understood ... Into a-into probably a nicer human being, if I can put it that way.

While other scientists spoke of following the rules of religion to be ethical, this scientist saw religion as something that can help a person subconsciously develop an inherent sense of ethics and morality that will stay with them throughout their life. Although this view of religion as supporting ethical behavior emerges in other national contexts, it may not be as prevalent as it is among Indian scientists. This perspective is most common among scientists who view religion and science as in

IND_49: Biology, Principal Scientist, religious, Hindu, male.

IND_24: Biology, Graduate Student, slightly religious, Hindu male.

IND_28: Biology, Associate Professor, religious, Muslim, male.

IND_30: Biology, Professor Emeritus, religious, Muslim, male.

IND_34: Biology, Professor, slightly religious, Muslim, female.

IND_33: Biology, Professor, slightly religious, Muslim, male.

IND_35: Biologist, Assistant Professor, slightly religious, Hindu, male. 
collaboration, although some scientists with other views on the relationship between religion and science articulate this view as well.

\subsection{Religious Rituals}

Another common component of our respondents' definitions of religion was ritual practice. Our respondents consistently emphasize this element of religion, pointing to specific festivals or ritual practices within religion, generally drawing on Hinduism, the dominant religious tradition of their cultural context, to do so. For many of our respondents, religious rituals and practices are seen as positive elements of religion, which benefit scientific work. One way in which scientists make this connection is to link regular prayers to developing discipline, arguing that having discipline in religious practice translates into discipline in carrying out their work as scientists. A professor of biology ${ }^{9}$ illustrates this, saying:

it [religion] also inspires us to be disciplined you know. Like we are having the prayers, which are having definite timings you know. That means you have to get up early in the morning for the first prayer and then after that late in the night, so that means there are five times, which are fixed for the prayer. I mean it's just one thing you can say that if you are disciplined you know, so that is also one of the important factors when you are doing science, when you are doing any work, if you are disciplined that will definitely help you.

This respondent is speaking about Islam and the requirement that all Muslims pray five times a day. For her, regular prayer teaches her discipline and that discipline is a resource for her in all other aspects of her life, including her scientific work.

While many of the Indian scientists we studied felt that religious rituals have a positive impact on other spheres of life, other respondents' descriptions of religious rituals suggested a much more negative perspective. For example, in telling us how she defines religion, a physics professor ${ }^{10}$ pointed to Hinduism, saying: "Today is a special festival, you have to do this. You have to go to the temple, do this, do that, do that." In saying this, the respondent focuses on religious practices expected of practitioners, but she spoke of them mockingly, expressing distaste with the regulatory nature of religion. Similarly, an associate professor of biology ${ }^{11}$ said that "generally they ... don't question these things, only he has to follow or she has to follow whatever there is in their religion. If there are questions, then there may be some problems." Thus, religion and religious rituals can become blinding. A physics graduate student, ${ }^{12}$ who coincidentally believed that religion provides good principles, also felt people could sometimes follow religions blindly:

... The good part of religion is that it's a proper, distinct way of living a life with following certain rules. But sometimes I've seen people becoming-some blind ideals about those rules, and they forfeit questioning that rules. So, for me, I should never-if I'm asked to do something I should think once or twice why I'm doing that, but you know too much religious mind can stop you from doing that.

It seems that for these respondents, followers of religion can become blinded by their religion. This, coupled with the previous theme of religion providing good principles for life, shows a rather mixed feeling among these scientists towards religion. This perception of religion as rigid was echoed by many of our respondents. It is important to note that these religious rituals are often tied to specific religious traditions, as are the criticisms some respondents level against religion. For instance, as a biology graduate student ${ }^{13}$ put it, “ ... religious is quite different. It's more of a, um, a strict path sort

\footnotetext{
IND_34: Biology, Professor, slightly religious, Muslim, female.

IND_55: Physics, Professor, slightly religious, Hindu, female.

IND_32: Biology, Associate professor, religious, Muslim, male.

IND_62: Physics, Graduate Student, non-religious, no religious affiliation, male.

IND_22: Biologist, PhD student, non-religious, Sikh, female.
} 
of a thing like a defined part sort of a thing that if I'm a Hindu I'm supposed to do this. If I'm Sikh, I'm supposed to do this ... " Here religion is conceptualized as a "strict path," which once again hints at the ethical dimensions of religious belief. Yet, as the respondent explains, this ethical dimension looks different for Hindus compared to Sikhs, as each one has a different path that they are supposed to follow. Although the assumption might be that there would be considerable overlap for religions co-existing within the same country, India's well-documented history of religious conflict suggests that the differences between such paths are significant.

\subsection{Religion as Tradition}

We also found that many of our respondents defined religion as something received from family. The idea of being "born into" religion was common amongst our respondents, who often spoke of inheriting their religion. Often, this inherited religion was connected to a sense of ethics, as religious identity was once again tied to certain practices. One biology graduate student ${ }^{14}$ got at this sense of the ties between birth and behavior in defining religion saying: “Okay, so I mean for me it's just- it is a set of, a set of traditions and set of, kind of guidelines that you follow because of the place, because of the settings you are born in." Here guidelines and traditions are connected to place, as one's birth shapes the set of traditions they will be obligated to follow. Religious identity is seen as pre-determined in that it depends on family religious beliefs rather than the individual's choice.

In this way, religious identity is not chosen, and neither can it be given up. Such a view has interesting repercussions for scientists, especially given the prevailing narrative of the secularizing influence of scientific work at the individual level. One biology scientist ${ }^{15}$ provides a helpful analogy for explaining such a tension in saying

I think I would define this in a very loosely like, [religion] is something ancestral and since there is no need to either break away from that tradition, because it is known to us, harmless, attached to we because of my birth in certain family, it is being carried forward. Just like ancestral property. You might be a communist, might not like the property, but you have inherited the property, so you will keep it.

The analogy used for religion is property; just as one might inherit land, one also might inherit religion. Similarly, whether one wants the property or not, they will keep it, because it was inherited. This biologist points out several reasons for holding onto religion, as he sees it as ultimately "harmless," meaning there is no need to "break away from tradition." One may not like religion, or might be opposed to religion (as a communist is opposed to private property), but one will hold onto religion because it was given by family. Such a position does not seem to be dictated by any sense of sentimentality as much as a conceptualization of religion as an ascribed identity.

The view of religion as ascribed also has interesting repercussions considering our respondents' view of religion as a source of ethics. In this sense, how people act is dictated by religion, which in turn is dictated by ancestry. One physics professor, ${ }^{16}$ who also identifies as a Jain, gets at this dialectic between religion and behavior in saying

When I said religion is a way of life, I have been born in a family which is, by definition, a vegetarian family. A vegetarian not by choice but vegetarian by religion. So until death, I am a vegetarian. So to that extent I am religious.

In this quote, religion is defined in terms of a certain behavior, in this case, vegetarianism. In fact, the respondent even defines his own religiosity in terms of his commitment to vegetarianism. Such

\footnotetext{
IND_11: Biology, Graduate student, slightly religious, Hindu, female.

IND_26: Biology, Scientist, non-religious, Hindu, male.

16 IND_72: Physics, Professor, slightly religious, Jain, male.
} 
a commitment is born not out of "choice" but rather "religion," as these two ideas are interestingly contrasted as opposites with the latter inherited through family. Similarly, not only is religion not chosen, it cannot be given up, the scientist emphasizes that they will be a vegetarian, or a Jain, until death. Such is the power of religion and family in the Indian culture. Similar to the theme of religion as a higher power, this theme was not linked to respondents' views of the relationship between religion and science.

\subsection{Religion as Differentiation}

Finally, a small number of our respondents described religion as a source of identity and a means of constructing boundaries between humans. For example, an assistant professor of physics ${ }^{17}$ argues that "Religion is just a source of differentiation of human beings," one that defines religion as a source of personal identity that is reflected in one's thoughts, deeds, and work. This respondent did not attach a negative meaning to this differentiation, however some of our respondents did. For example, a biology professor ${ }^{18}$ raised concerns about classism and the caste system in India, saying: "They [the so-called lower castes] were not even allowed access into the temple. But I think that's because these upper-caste people used religion, and in the name of religion tried to sanction so many things that otherwise would not be accepted by the masses." Thus, for her, religion serves to reinforce a social hierarchy and to disadvantage a large group of people within society. Although this was not a very common theme among our respondents, it demonstrates a connection between the caste system, a basic feature of religion in India, with conceptualizations of religion, particularly negative ones. This view of religion, particularly the focus on caste, is unique to Hinduism.

\section{Definitions of Spirituality}

Many of our respondents struggled to speak about the concept of spirituality; it often seemed to be foreign to their language and experience. This is ironic given common perceptions of India's rich spiritual history, and the influence of India on spirituality in the West (Goldberg 2010). Among those who did offer a definition of spirituality, the most common theme was the view that spirituality is linked to ethics and morality, emerging among 17 respondents. A second common theme in definitions of spirituality is the view that spirituality is individualistic, with 13 respondents saying that it is personal and often provides an individualized set of ethical guidelines for the treatment of others. Finally, 10 respondents described spirituality as a source of emotions, particularly peace and tranquility. Overall, we found that our respondents' definitions of spirituality were characterized by more variation than their definitions of religion. Respondents in each category of the survey question saw spirituality as ambiguous, a source of individual ethics, and a source of peace and calm.

\subsection{Ambiguity of Spirituality}

When asked to define spirituality, respondents from India consistently struggled, as they were often unable to articulate this concept. This is well illustrated by a postdoctoral fellow in physics ${ }^{19}$ who said: "I still do understand something about what is religion, but I really don't think I understand spirituality." She went on to explain her inability to define the term by saying: "I have not felt in that spirituality, so I couldn't say much." This suggests that spirituality is something that must be experienced to be understood or even comprehended. When respondents did offer a definition for spirituality, they often gave their answer with a caveat. For example, a biology professor ${ }^{20}$ said: "I may not be able to put it exactly in words," hesitant to give a clearly defined definition of the term. Although

\footnotetext{
IND_40: Physics, Assistant Professor, non-religious, no religious affiliation, male

IND_08: Biology, Professor, non-religious, Hindu, female.

IND_15: Physics, Postdoctoral fellow, slightly religious, Hindu, female.

IND_71: Biology, Professor, slightly religious, Sikh, male.
} 
respondents sometimes needed time to respond to our questions about religion, they were much more willing to offer definitions of religion than they were spirituality. This suggests that the concept of spirituality may not translate directly to non-Western contexts such as India.

\subsection{Spirituality as Individual Ethics}

Among those respondents who did offer definitions of spirituality, they often emphasized ethical and moral guidance that can be derived from spirituality. This element was also common in our respondents' definitions of religion, however, when discussing spirituality, respondents put it in more humanistic terms. A biology PhD student ${ }^{21}$ illustrates this, saying "It has to do with human thought and human behavior ... One could even maybe-sometimes I wonder if I can consider myself spiritual in a way, only because I think about issues that are not directly day-to-day or materialistic. Maybe I do think about things like goodness and ethics and morality and-but that has nothing to do with religion." This respondent understands spirituality as making an attempt to move beyond material concerns towards broader concerns about ethics and the treatment of others. Further, she is clear to say that this cannot be understood the province of religion. A graduate student studying biology ${ }^{22}$ said, "That spirituality is more towards looking within yourself, how you would keep yourself away from the good versus the bad and this should be done, this should not be done, stuff like that." While it is obvious that the scientists' conceptualizations of religion and spirituality overlap in that they are both sources for guidelines in behavior; spirituality, as opposed to religion, involves "human thought" and "looking within [one]self." For our respondents, these elements of spirituality often gave the term a positive connotation whereas religion had a negative connotation.

\subsection{Spirituality as Individual}

Our respondents also defined spirituality as something internal and individual. This definition is consistent with what the literature would suggest; that spirituality is oriented towards the individual whereas religion is oriented towards the community (Zinnbauer et al. 1997). A biology professor ${ }^{23}$ directly points out that "you get some inner power, inner-that is something that you get a sort of contentment and a sort of pleasure from your inside, from your inner-being." Moreover, spirituality requires "self-knowledge" and self-consciousness, according to a retired physics professor, ${ }^{24}$ "It has to be done by yourself. You cannot get it from a book, which doesn't not mean don't read books. It just tells you that knowledge will not take you there. It requires more than knowledge." Thus, personal discovery and exploration is a key component of spirituality in that it is essential to the development of spirituality ${ }^{25}$. A PhD student in biology ${ }^{26}$ draws this out further, saying "I may not be Hindu, if I am a Hindu, I may not be having that concern towards spirituality through the Hinduism. I may follow some other route. I may be more interested, I may believe more into a Christianity point of view to be spiritual or something, so being spiritual, because these are all the different [routes] to being a spiritual ..." Thus, for this respondent, religion and the various forms of spirituality are all simply paths to the same goal, the goal of becoming spiritual. In this framing, religion is a casing for spirituality. Further, it frames spirituality as uniquely individual, contrasting understandings of religious identity as ascribed and maintained because of family background and family expectations.

\footnotetext{
IND_09: Biologist, Professor, non-religious, no religious affiliation, female.

IND_11: Biology, PhD Student, slightly religious, Hindu, female.

IND_34: Biology, Professor, slightly religious, Muslim, female.

IND_13: Physics, Professor Emeritus, religious, no religious affiliation, male.

This resembles the concept of Advaita Vedanta or self-realization in Hinduism (Johnson 2010).

IND_22: Biologist, PhD student, non-religious, Sikh, female.
} 


\subsection{Spirituality as Emotions}

Many of our respondents felt that spirituality involves emotions and nature. Respondents often describe spirituality as experienced in moments of "peace," "calmness," and "happiness." For example, a biology graduate student ${ }^{27}$ explains that "That's a feeling of that calmness, calming of the spirit where despite whatever the negatives or whatever the anthropic [lack of balance] in my surroundings, I'm at peace with myself and I'm able to spread that." This demonstrates that spirituality serves to relieve daily stresses and create a sense of calm in the face of imbalance, helping to avoid stress or anxiety. Similarly, a biology research scientist ${ }^{28}$ describes his perception of spirituality as, "people going into some setting where they really are able to obtain a lot of peace and happiness and are free of any worries and any of their daily tensions and stuff like that." Thus, for these respondents, spirituality separates and frees people from the burdens or pressures of daily life, or the mundane world, while bringing people tranquility and joy. Nature is a particular setting understood as spiritual that elicits a calming emotional response. This theme in our data illustrates the functional aspect of respondents' understandings of spirituality.

Overall, our data reveal some important differences between religion and spirituality, where the former is ascribed through family communities and the latter is individually developed and based around experience. Functionally, our respondents see religion as a source of rules and guidelines for behaviors and spirituality as a basis for encouraging ethical treatment of others and a source of emotional calm. What remains unclear, however, is what these findings can reveal about scientists' understandings of the relationship between religion and science. In the following section, we analyze the ways they are connected.

\subsection{Relationship of Religion, Spirituality, and Science}

Examining our respondents' definitions of religion and spirituality in conjunction with their views on the relationship between religion and science reveals several important themes. One of these emerged with regard to respondents' perspectives on rules and behavioral guidelines in religion. Some respondents viewed religious rules as a benefit to society. For example, one biology professor ${ }^{29}$ said "for me we have a faith in certain ideology whatever you can say, Christians may be believing in something, Muslims believing in something, but I think if you believe in something, maybe we do less of crime activity, or nefarious activity." This respondent clearly sees benefits to religious belief, suggesting that it discourages people from committing crime and breaking the law. Further, he argues that this is true of religion broadly speaking, not specific to his own faith. Respondents who articulated this perception of religion, where religion makes people "better," rarely saw any conflict between religion and science. In fact, respondents who articulate this perspective sometimes brought up ways religious values may support scientific endeavors.

In contrast, other respondents argued that using religion as a source of rules and values is a form of social control and an illustration of blind faith, and those who articulated this perspective often felt that religion and science were in conflict. A biology graduate student ${ }^{30}$ illustrates this saying "I do believe that religion was introduced into the human race just because they wanted to put these rules of right and wrong and if you do this thing, if you're committing a sin and blah blah, whatever ... Religion is you are following and abiding by the rules put up by the humans themselves, just-it's basically a social control." Thus, this respondent has a very different perspective from the respondents discussed earlier. Although she agrees that religion is a source of rules and values in society, she sees this as a tool constructed by people to control others. This difference in views of religion is linked

\footnotetext{
IND_24: Biology, Graduate Student, slightly religious, Hindu, male.

IND_18: Biology, Research Scientist, religious, Hindu, male.

IND_33: Biology, Professor, slightly religious, Muslim, male.

IND02: Biology, Graduate Student, non-religious, Hindu, female.
} 
to the way respondents view the relationship between religion and science, where religion requires unquestioning acceptance of the guidelines they profess, and such unquestioning acceptance runs counter to a scientific worldview. For example, another biology graduate student ${ }^{31}$ describes religion as offering a particular understanding of the world and requiring acceptance of it, saying "religions won't allow you to question them in detail or criticize them. There are some prominent religions but yeah, so most of the religions don't allow you to question them, and they direct your life in a way about what you should do on this day or what you should not do on this day or that day." Such understandings of religion are articulated in sharp contrast to respondents' understanding of science, a field based entirely around exploration. When respondents see religion as characterized by blind faith and unquestioning acceptance, this comes into sharp conflict with their professional values focused on systematic exploration and discovery in science. Participation in religion then comes at the cost of their professional values. A graduate student in physics ${ }^{32}$ demonstrates this well, saying "sometimes I've seen people becoming - some blind ideals about those rules, and they forfeit questioning that rules. So, for me, I should never-if I'm asked to do something I should think once or twice why I'm doing that, but you know too much religious mind can stop you from doing that." This respondent draws a clear link between the professional values of science and what they see as a common characteristic of religion and religious belief. For this respondent, unquestioning belief is clearly seen as problematic and common among religious people, although he does not think it is universal to the religious. More broadly, we found that respondents who articulated this perception of religion, as requiring blind faith, often saw religion and science as in conflict.

Another theme in respondents' definitions of religion was an emphasis on ritual. We find that respondents who describe the positive impact of religious rituals in their life and their scientific work often view religion and science as in collaboration with each other. Few see religion and science as in conflict, and when they do, they often suggest that it may conflict for others but is not inherent to religion and science. However, in some cases respondents felt that religious rituals and practices were followed blindly. Once again, they saw this as conflicting with a scientific worldview, and those who articulated this point were among the respondents who felt that religion and science were in conflict. These respondents felt that religious rituals were problematic, describing ways that the emphasis on ritual can become blinding and limit individual freedom and curiosity. This perspective consistently emerged among scientists who saw religion and science as in conflict, as well as some who saw religion and science as independent. Finally, where respondents saw religion as a source of identity and a basis for the construction of boundaries (i.e., the caste system) these respondents were often ones who saw religion and science as in conflict.

We find clear patterns between definitions of religion and views on the relationship between religion and science, where respondents who understood various elements of religion (beliefs, practice, ritual) as requiring blind and unquestioning commitment, were also among those who saw religion and science as in conflict. In contrast, respondents who saw religion and science as in collaboration, brought up the benefits religious practices and guidelines can bring even to scientific work-for example, discussing the ways religious practice can teach discipline and how such discipline benefits all other spheres of life, including their work as scientists. Respondents who felt that religion and science were independent were marked by the most variation in terms of their definitions of religion and science, with some who were similar to those who described conflict, and others who resembled those who described collaboration. Our findings illustrate that the conflict statement is tied to particular understandings of religion. Knowing the characteristics of such understandings of religion is necessary to create a dialogue and build a bridge between the spheres of religion and science.

31 IND_23: Biology, Graduate Student, non-religious, no religious affiliation, male.

32 IND_62: Physics, Graduate Student, non-religious, no religious affiliation, male. 


\section{Discussion and Conclusions}

We find great variation among Indian scientists regarding their definitions of religion, their definitions of spirituality, and their view on the relationship between religion and science. The diversity in our respondents' narratives reflects the great diversity within India, in terms of religion and regional culture. Our results reveal some similarities between Indian scientists' definitions of religion and spirituality with those of the West, as well as several important differences. Similarities we found include spirituality being defined as very individualized, and definitions of spirituality being vague in comparison to definitions of religion. Religion was often understood for our Indian scientists as relating to belief in God or gods and the adherence to rituals and a moral code. Differences we found include the frequent highlighting of ritual for Indian scientists as something that could either aid or detract from scientific work, and the more common, in comparison to Western scientists, expression among Indian scientists of religion being associated with one's birth rather than as an active choice. Further, we find that respondents' views of religion are tied to their views on the relationship between religion and science, where those who believe they are in conflict highlight restrictive rituals and dogma, whereas those who believe science and religion are not in conflict focus on discipline and ethical guidelines.

Both definitions of religion and spirituality are characterized by some ambiguity; however, our results do suggest many similarities in Indian scientists' definitions of religion and spirituality with those common in the Western world, as well as some important differences. Similar to the way individuals understand spirituality in the West (Schlehofer et al. 2008), Indian scientists see spirituality as highly individualized. Further, similar to scientists in the US (Ecklund and Long 2011), Indian scientists see spirituality as a source of ethics, morality, and peace that allows them to do better scientific work. In line with existing literature (Schlehofer et al. 2008), we find that Indian scientists see spirituality as a vague and ambiguous concept and their definitions of spirituality are similarly vague and unspecified, perhaps characterized by even less clarity than individuals' definitions of spirituality in Western contexts. We also find that, akin to other scientists in the US (i.e., Ecklund and Long 2011), Indian scientists often define religion by belief in God, religious rituals, and a moral code.

However, we find that these understandings of religion are filtered through the Indian context and the dominant religious tradition of India-Hinduism. This emerges most clearly in our respondents' discussion of religious rituals, both in terms of their involvement in religious rituals and their criticisms of these rituals. In fact, the ritual element of religion is often highlighted among Indian respondents. This is likely because of the centrality of religious ritual and practice in Hinduism when compared to other religious traditions such as Christianity. Although this finding does not contradict expectations of how Indian scientists may define religion, it demonstrates the ways definitions of religion are constructed differently in various national and cultural contexts. Similarly, some of our respondents described religion as a source of differentiation in society and illustrated this by discussing the caste system. This focus on differentiation, and on caste in particular, is unique to Hinduism.

Indian scientists' views of religion are also unique in their description of religion as ascribed by birth. Many of our respondents said that because their family identified with a particular religious tradition, they identified with and participated in the same tradition. This view of religion came up for respondents from a range of religious backgrounds. When describing their engagement in religion, these respondents say they do participate in religious practices, but they frame these practices by describing them as simply what their family has always done, and thus it is what they will do. This marks a sharp divergence from Western contexts, particularly the US, where religion is persistently understood through the lens of individualism (Bellah 1985). In the American context, at least when it comes to individuals' narratives of religious belief and practice, religion is an achieved identity. It is important to note that Indian scientists' descriptions of religion, as ascribed, do not characterize all our respondents. There were some Indian scientists we spoke with who described a much more involved role in constructing their religious identity, beliefs, and practices; however, this was much more common in their descriptions of spirituality rather than religion. 
Finally, our results reveal that definitions of religion are linked to the way respondents view the relationship between religion and science. One illustration of this is in the way our respondents viewed the guidelines offered by religion. Many of our respondents' definitions of religion highlighted this characteristic; however, there was a divide between respondents in perceiving moral guidelines as positive or negative. Respondents who saw religion as a source of positive moral guidelines often described these as socially beneficial, even discussing the ways they contributed to their scientific work. They felt that the moral guidelines provided by religion made people better in general and the discipline required for certain religious practices also served them in their scientific endeavors.

Those who saw these guidelines as negative often described them as created by humans, requiring blind faith, and creating harmful distinctions between social groups. These respondents felt that the rules and regulations of religion stifle scientific inquiry by limiting curiosity, a fundamental norm of science (Merton 1973). These differences in the portrayal of religion are linked to the ways scientists viewed the relationship between religion and science, where those who took a more positive stance tended to describe religion and science as in collaboration, and those who took a more negative stance, and particularly those who saw religion as requiring blind faith, described religion and science as in conflict. Thus, there is a connection between views on the relationship between religion and science and definitions of religion. In seeking pathways to mediate the perceived conflict between science and religion, it is essential to address assumed characteristics of religion.

Although views on the relationship between religion and science were meaningful when it came to understandings of religion, they were less informative when it came to definitions of spirituality. This suggests that spirituality has yet to become enmeshed in this tension between religion and science. In fact, in line with Ecklund and Long (2011), many of our respondents suggest that spirituality is consist with their scientific work. The ambiguity of the concept of spirituality may support this flexibility, as individual scientists are able to easily frame the concept in ways that are consistent with other spheres of their life.

Overall, we find that Indian scientists' definitions of spirituality are largely consistent with what the literature has found when comparing scientists in other national contexts. Further, we find that definitions of religion, if not spirituality, are tied to views on the relationship between religion and science. If anything, Indian scientists' definitions of spirituality may be characterized by greater ambiguity because due to less familiarity with the term, as it is thought of in the West, respondents were less likely to have a preconceived understanding of its meaning for themselves. Indian scientists' definitions of religion are also consistent with what would be expected from the literature. We do find, however, that the elements of religion which are often highlighted in definitions of religion, such as belief in God and religious ritual, are filtered through the dominant religious tradition of the Indian context-Hinduism. Further, Indian scientists diverge in their discussion of the reasons for their religious convictions, with many scientists explaining their religious commitments in terms of family tradition. This suggests that although the elements of definitions of religion and spirituality are common to Indian scientists, important variation emerges in terms of the way they experience and relate to religion. Finally, definitions of religion are tied to views on the relationship between religion and science, where those who take a conflict perspective believe that religion conflicts with the fundamental norms of science. Attempts to mediate this conflict must take these understandings of religion into account and seek to address them.

Future research should continue to study definitions of religion and science. This literature would benefit from a comparison of the general public's definitions with scientists' definitions of religion and spirituality. This would allow scholars to tease out the influence of working in science on understandings of religion and spirituality. Similarly, future research should examine the ways scientific institutions in various national contexts reinforce or refute particular understandings of religion and spirituality. Such research would address the mechanisms through which various understandings of religion and spirituality are reproduced. To fully understand both religion and the influence of science across the globe, we must study variation in religion and how this emerges among scientists themselves. 
Author Contributions: Conceptualization, S.K. and E.H.E.; Formal analysis, S.K. and E.H.E.; Funding acquisition, E.H.E.; Writing-original draft, S.K. and E.H.E.; Writing-review \& editing, S.K., E.H.E. and B.D.K. All authors have read and agreed to the published version of the manuscript.

Funding: This research was funded by the Templeton World Charity Foundation, "Religion" among Scientists in International Context, TWCF0033/AB14, Elaine Howard Ecklund PI, Kirstin R. W. Matthews and Steven Lewis, Co-PIs.

Conflicts of Interest: The authors declare no conflict of interest.

\section{References}

Ammerman, Nancy T. 2013. Spiritual But Not Religious? Beyond Binary Choices in the Study of Religion. Journal for the Scientific Study of Religion 52: 258-78. [CrossRef]

Baker, Joseph O. 2012. Perceptions of Science and American Secularism. Sociological Perspectives 55: 167-88. [CrossRef]

Bellah, Robert N. 1985. Habits of the Heart: Individualism and Commitment in American Life. New York: Harper and Row.

Bhargava, Rajeev. 2010. The Promise of India's Secular Democracy. New York: Oxford University Press.

Bhattacharya, Sabyasachi. 2011. Indian Science Today: An Indigenously Crafted Crisis. Social Research 78: 255-80.

Bhattacharyya, Harihar. 2001. Indian Federalism and Indian Communism: Conflict and Collaboration. The Indian Journal of Political Science 62: 41-60.

Brooke, John Hedley, and Ronald L. Numbers, eds. 2011. Science and Religion around the World. New York: Oxford University Press.

Brown, C. Mackenzie. 2012. Hinduism and Science: Contemporary Considerations. Zygon 47: 608-23. [CrossRef] Burdett, Michael S. 2017. Assessing the Field of Science and Religion: Advice from the Next Generation. Zygon 52: 747-63. [CrossRef]

Census of India. 2011. Available online: http://censusindia.gov.in/Census_And_You/religion.aspx (accessed on 1 June 2020).

Chandhoke, Neera. 1999. Beyond Secularism. New York: Oxford University Press.

Chandra, Shefali. 2015. 'India Will Change You Forever': Hinduism, Islam, and Whiteness in the American Empire. Signs 40: 487-512. [CrossRef]

Chaves, Mark. 1994. Secularization as Declining Religious Authority. Social Forces 72: 749-75. [CrossRef]

Coosona, Greg. 2016. Some Ways Emerging Adults are Shaping the Future of Religion and Science. Zygon 51: 557-72. [CrossRef]

Coulborn, Rushton. 1958. The State and Religion: Iran, India, and China. Comparative Studies in Society and History 1: 44-57. [CrossRef]

Das Acevedo, Deepa. 2013. Secularism in the Indian Context. Law \& Social Inquiry 38: 138-67.

Dawkins, Richard. 2006. The God Delusion. Boston: Houghton Mifflin Co.

Ecklund, Elaine Howard. 2010. Scientists Vs. Religion: What Scientists Really think. London: Oxford University Press.

Ecklund, Elaine Howard, David R. Johnson, Brandon Vaidyanathan, Kirstin R. W. Matthews, Steven W. Lewis, Robert A. Thomson Jr., and Di Di. 2019. Secularity and Science: What Scientists around the World Really Think about Religion. New York: Oxford University Press.

Ecklund, Elaine Howard, and Elizabeth Long. 2011. Scientists and Spirituality. Sociology of Religion 72: 253-74. [CrossRef]

Garelli, Franco. 2007. Research Note Between Religion and Spirituality: New Perspectives in the Italian Religious Landscape. Review of Religious Research 48: 318-26.

Giri, Ananta Kumar. 2005. Spiritual Cultivation for a Secular Society. Sociological Bulletin 54: 7-100. [CrossRef]

Goldberg, Philip. 2010. American Veda: From Emerson and the Beatles to Yoga and Meditation: How Indian Spirituality Changed the West. New York: Harmony.

Gosling, David L. 2007. Science and the Indian Tradition: When Einstein Met Tagore. New York: Routledge.

Hautman, Dick, Stef Aupers, and Paul Heelas. 2009. A Rejoinder to Flere and Kirbiš: Christian Religiosity and New Age Spirituality: A Cross-Cultural Comparison. Journal for the Scientific Study of Religion 48: 169-79. [CrossRef] 
Hill, Peter C., Kenneth I. Pargament, Ralph W. Hood Jr., James P. Swyers, David B. Larson, and Brian J. Zinnbauer. 2000. Conceptualizing Religion and Spirituality: Points of Commonality, Points of Departure. Journal for the Theory of Social Behavior 30: 51-77. [CrossRef]

Jaeshik, Shin. 2016. Mapping One World: Religion and Science from an East Asian Perspective. Zygon 51: $204-24$. [CrossRef]

Johnson, W.J. 2010. Oxford Dictionary of Hinduism. Oxford: Oxford University Press, pp. 5-6.

Keller, Barbara, Constantin Klein, Anne Swhajor-Biesemann, Christopher F. Silver, Ralph Hood, and Heinz Streib. 2013. The Semantics of Spirituality and Related Self-Identifications: A Comparative Study in Germany and the USA. Archive for the Psychology of Religion 35: 71-100. [CrossRef]

Kumar, Duru Arun. 2012. Technology Growth in India-Some Important Concerns. Polish Sociological Society 178: 295-302.

Larson, Edward J., and Larry Witham. 1997. Scientists are Still Keeping the Faith. Nature 386: 435-36. [CrossRef] Larson, Edward J., and Larry Witham. 1998. Leading Scientists Still Reject God. Nature 394: 313. [CrossRef]

Leuba, James H. 1916. The Belief in God and Immortality: A Psychological, Anthropological, and Statistical Study. Boston: Sherman, French, \& Co.

Madan, T.N. 1987. Secularism in its Place. The Journal of Asian Studies 46: 747-59. [CrossRef]

Madan, T.N. 1989. Religion in India. Daedalus 118: 114-46.

Marler, Penny Long, and C. Kirk Hadaway. 2002. 'Being Religious' or 'Being Spiritual' in America: A Zero-Sum Proposition? Journal for the Scientific Study of Religion 41: 289-300. [CrossRef]

Martin, Cesar, and Guillermo D’Elia. 2016. Effect of Academic Degree and Discipline on Religious Belief and Evolution Acceptance: Survey at a Chilean University. Zygon 51: 277-92. [CrossRef]

Merton, Robert K. 1973. The normative structure of science. In The Sociology of Science: Theoretical and Empirical Investigations. Chicago: University of Chicago Press.

Norris, Pippa, and Ronald Inglehart. 2004. Sacred and Secular: Religion and Politics Worldwide. New York: Cambridge University Press.

North, David. 1995. Soothing the Establishment: The Impact of Foreign-Born Scientists and Engineers on America. Lanham: University Press of America.

PEW. 2015. Available online: http://www.pewforum.org/2015/05/12/americas-changing-religious-landscape/ (accessed on 6 June 2020).

Prakash, Gyan. 2007. Secular Nationalism, Hindutva, and the Minority. In The Crisis of Secularism in India. Edited by Anuradha Dingwaney Needham and Rajeswari Sunder Rajan. London: Duke University Press, pp. 177-88.

Quack, Jonathan. 2012. Disenchanting India: Organized Rationalism and Criticism of Religion in India. New York: Oxford University Press.

Raina, Dhruv. 2012. Decolonization and the Entangled Histories of Science and Philosophy in India. Polish Sociological Review 178: 187-201.

Rajan, Rajeswari Sunder, and Anuradha Dingwaney Needham. 2007. Introduction. In The Crisis of Secularism in India. Edited by Anuradha Dingwaney Needham and Rajeswari Sunder Rajan. London: Duke University Press, pp. 1-42.

Rinehart, Robin. 2004. Contemporary Hinduism: Ritual, Culture, Practice. Santa Barbara: ABC-CLI.

Schlehofer, Michele M, Allen M. Omoto, and Janice R. Adelman. 2008. How Do 'Religion' and 'Spirituality' Differ? Lay Definitions Among Older Adults. Journal for the Scientific Study of Religion 47: 411-25. [CrossRef]

Schofer, Evan. 2003. The Global Institutionalization of Geological Science, 1800 to 1900. American Sociological Review 68: 730-59. [CrossRef]

Schott, Thomas. 1993. World Science: Globalization of Institutions and Participation. Science, Technology, and Human Values 18: 196-208. [CrossRef]

Schott, Thomas. 1998. Ties Between Center and Periphery in the Scientific World System: Accumulation of Rewards, Dominance, and Self-Reliance in the Center. Journal of World-Systems Research 4: 114-44. [CrossRef]

Sen, Amartya. 2005. The Argumentative Indian: Writings on Indian History, Culture, and Identity. New York: Farrar, Straus, and Giroux.

Sen, Ragini, Wolfgang Wagner, and Caroline Howarth. 2013. Secularism and Religion in Multi-Faith Societies: The Case of India, 1st ed. Cham: Springer International Publishing. 
Sidhu, Gurkirpal Singh. 2006. GATS and Higher Education: India Moving Towards Global Markets. Indian Journal of Political Science 67: 381-96.

Smith, Christian, Brandon Vaidyanathan, Nancy T. Ammerman, José Casanova, Hilary Davidson, John H. Evans, Philip S. Gorski, Mary Ellen Konieczny, Jason A. Springs, Jenny Trinitapoli, and et al. 2013. Roundtable on the Sociology of Religion: Twenty-Three Theses on the Status of Religion in American Sociology-A Mellon Working-Group Reflection. Journal of the American Academy of Religion 81: 903-38. [CrossRef]

Southgate, Christopher. 2016. Science and Religion in the United Kingdom: A Personal View on the Contemporary Scene. Zygon 51: 361-86. [CrossRef]

Stark, Rodney, Laurence R. Iannaccone, and Roger Finke. 1996. Religion, Science, and Rationality. The American Economic Review 86: 433-37.

Stephan, Paula E., and Sharon G. Levin. 2001. Exceptional Contributions to U.S. Science by the Foreign-Born and Foreign-Educated. Population Research and Policy Revieww 20: 59-79. [CrossRef]

Taylor, Charles. 2016. Can Secularism Travel? In Beyond the Secular West. Edited by Akeel Bilgrami. New York: Columbia University Press.

Tejani, Shabnum. 2007. Reflections on the Category of Secularism in India. In The Crisis of Secularism in India. Edited by Anuradha Dingwaney Needham and Rajeswari Sunder Rajan. London: Duke University Press, pp. 45-65.

Weber, Max. 1918. Wissenschaft als Beruf. München: Munich University.

Wuthnow, Robert. 1988. The Restructuring of American Religion: Society and Faith Since World War II. Princeton: Princeton University Press.

Wuthnow, Robert. 1998. After Heaven: Spirituality in America since the 1950s. Berkeley: University of California Press.

Zinnbauer, Brian J., Kenneth I. Pargament, Brenda Cole, Mark S. Rye, Eric M. Butter, Timothy G. Belavich, Kathleen M. Hipp, Allie B. Scott, and Jill L. Kadar. 1997. Religion and Spirituality: Unfuzzying the Fuzzy. Journal for the Scientific Study of Religion 36: 549-64. [CrossRef]

(C) 2020 by the authors. Licensee MDPI, Basel, Switzerland. This article is an open access article distributed under the terms and conditions of the Creative Commons Attribution (CC BY) license (http://creativecommons.org/licenses/by/4.0/). 